\title{
Bureaucratisation of the Teaching Profession in Decentralised Vocational Education-The Case of Slovenia, Europe
}

\author{
Klara Skubic Ermenc ${ }^{1}$ \& Jasna Mažgon ${ }^{1}$ \\ ${ }^{1}$ Faculty of Arts, University of Ljubljana, Ljubljana, Slovenia \\ Correspondence: Jasna Mažgon, Department of Educational Sciences, Faculty of Arts, University of Ljubljana, \\ Aškerčeva 2, SI-1000 Ljubljana, Slovenia. Tel: 386-41-634-285. E-mail: jasna.mazgon@ff.uni-lj.si
}

Received: November 27, 2014

doi:10.5539/ies.v8n5p12

\author{
Accepted: January 6, 2015 Online Published: April 27, 2015 \\ URL: http://dx.doi.org/10.5539/ies.v8n5p12
}

\begin{abstract}
Since 2001, Slovenian vocational education has undergone major changes at the curricular and financing levels, particularly moving towards competence-based and open curricula and the decentralisation of responsibilities. Both tendencies have changed the role of the teacher, who has become a team worker with many new responsibilities in planning, assessment and evaluation of the pedagogical process. Reform measures are regularly evaluated, and research findings are an important source of information for reforms. In our secondary analysis of selected evaluations, we attempt to prove our thesis that the teacher's autonomy has, despite this decentralisation, not increased in terms of better conditions for the students' development. Instead, it has resulted in teachers becoming exhausted by paperwork, the purpose of which they do not realise due to poor training and difficult working conditions. The article proves that the potential positive outcomes of the reforms can be lost if reform instruments are abused for political and/or economic purposes, if the swiftness and content of the reforms are dictated by the European (financial) policies and particularistic political interests, and/or if the school is reformed according to the rules of the market.
\end{abstract}

Key words: VET reform, Slovenia, competence-based curriculum, open curriculum, decentralisation, autonomy, curriculum planning

\section{Introduction}

Slovenia structurally reformed its vocational education and training (VET) after state independence. The first comprehensive concept was designed in 1992 (Medveš \& Muršak, 1992), and the new legislation based on this concept was adopted in 1996. The programmes had been reformed since 1998, but the process accelerated after 2001, when the Starting Points for Curricular Reform (Izhodišča, 2001) were adopted following a critical evaluation of the programmes.

In 2004, Slovenia became a full member of the EU and has since then been eligible to capitalize on the European Structural Funds, which opened up the possibility to continue the reform of all VET educational programmes, and in doing so translating into practice European recommendations. The EU charted its course towards the objectives 2010: The Lisbon Strategy was launched with the strategic objective of making Europe the most dynamic and knowledge based economy in the world. The aims of the strategy were to improve the quality of education and training systems, to facilitate the access to the education system for all and to open up the system to the wider world. The Copenhagen Declaration (Declaration of the European Ministers..., 2002) set out the expansion of the European dimension, called for greater transparency, defined the links between competences and qualifications, and lent support to quality assurance. Furthermore, the Maastricht Communiqué (2004) laid down priorities at national level by linking them to the European dimension-translating the Copenhagen objectives and tools into practice, raising investment in VET, taking into account the needs of risk groups, developing flexible and individualised learning paths, extending partnership, identifying the real needs for professional knowledge, developing and upgrading teacher competence and the learning environment, assisting in competence development and pinpointing learning needs in VET teachers (Kovač, 2007, p. 9).

On the basis of the Starting Points, the curricular reform was implemented by the National Institute for Vocational Education and Training (CPI) as the central national institution for VET monitoring and development, using a developmental programme (Kovač, 2007). In the beginning, two pseudo-experimental reforms were designed and programmes introduced to serve as case studies for the reform and introduction of other 
programmes. The plans for monitoring and evaluating both experiments were also prepared. When Slovenia became full member of the EU and more funds became available from the European Social Fund, two things happened. Even before the evaluation results from both experiments were known, an extensive reform of all VET programmes and their swift introduction was undertaken (the consequences are discussed below), and the CPI and its external collaborators conducted extensive evaluations. Our analysis of certain key issues regarding decentralisation and school and teacher autonomy is based on these.

VET reform involves remarkable decentralisation and autonomy of schools and teachers. This can be seen particularly in the changed VET financing, which is "based on the smallest unit in the education process, i.e., the student, providing for a greater autonomy of schools regarding their financing, organisation and syllabus" (Tome, 2008), as well as in the changed curriculum planning, with open national curricula and syllabi, which means that the final form and contents of each programme are influenced by the school leadership and teachers, as well as social partners and students (Ermenc, 2007, 2012; Pevec-Grm \& Škapin, 2006).

\subsection{The Effects of the Curricular Reform on VET Decentralisation}

This text focuses on the curricular aspect of decentralisation. Curricular reform, outlined in the 2001 Starting Points and operationalised in several legal documents and working materials, brought an extensive decentralisation of responsibilities unprecedented in the Slovenian system. The following major changes were introduced (Ermenc, 2012):

- For the first time, the state allows the schools to decide in which year and how professional modules are to be implemented.

- For the first time, one-fifth of the curriculum remains open for the purpose of allowing schools to provide contents corresponding to the needs of the local economy and raising the competitive value of their graduates.

- Competence-based syllabi bring the transfer of decision-making responsibility to schools regarding on-the-job learning; each school decides which professional modules are to include on-the-job learning, how much and when.

- The reform introduces the integrated key qualifications (competencies), a kind of trans- or inter-curricular educational objectives which the schools achieve through their own in various teaching subjects, modules and activities.

- The transfer of these responsibilities to schools also imposes on them mandatory self-evaluation and reporting on the achievement of goals.

Even this selected handful of the most radical changes demonstrates a great change in the role of the teacher in the VET system. In the centralised system, the tasks of the teacher were largely individualised, limited to the preparation of annual and everyday teaching plans, teaching and student assessments. But now, the teacher has become part of a team with new individual and group tasks in planning (the preparation of school curriculum), curriculum implementation and self-evaluation. Two categories of teachers were formed: team heads and team members.

\subsection{Autonomy and Decentralisation}

The concepts of decentralisation and autonomy are related, but not identical. With decentralisation, the autonomy of the school and the teachers can either increase or decrease (Eurydice, 2008a, 2008b; Koren, 2006; Lindblad, Lundahl, Lindgren, \& Zackari, 2002; Noordegraaf \& de Wit, 2012; Sahlberg, 2010; Udosen, 2014). In Slovenian pedagogy (Peček, 1998; Kroflič, 1999; Medveš, 2002; Resman, 2002; Marentič, Kalin, Šteh, \& Valenčič, 2005), the essence of the teachers' autonomy is understood in the context of their mission, i.e., educating students. The teachers hold their position in order to ensure an optimum development of all individuals regardless of various circumstances-to educate students about tolerance, respect for differences, cooperation, respect for children's and human rights, etc. It could be said that the autonomy should be increased in a manner that contributes to better achievements and better development of the learners. If the increase in the teachers' autonomy improves the quality of students' achievements and their overall development, it is sensible and correct.

In order for the teachers to function truly autonomously, certain requirements must be met. That is why the White Book on Education in the RS (2011) (Note 1) emphasises the importance of the teachers' continuous education and training. In order for the teachers to act in the interest of their students, they must have appropriate knowledge, as well as appropriate working conditions (space, equipment, time...) which the knowledge helps maximise and utilise. 


\subsection{The Problem, Research Questions and Hypotheses}

The key research problem is the issue of increased decentralisation and teacher autonomy, which did not prove positive and well-accepted among the teachers as it forced them into a new role with extended responsibilities and a lack of appropriate conditions for their performance. The problem seems to be two-fold: the extension of teachers' work tasks was not followed by a changed legal definition of teachers' responsibilities; and the changes were introduced with such haste that they could not be accompanied by teacher education and their psychological preparation for acceptance.

The problem was broken down into the following research questions:

(1) Did the curricular reform improve differentiation and individualisation of the teaching process?

(2) Did the introduction of the school curriculum provide for a better integration of general and vocational knowledge?

(3) What role and significance do the teachers and students attribute to the personal study plan?

(4) Is the new knowledge assessment paradigm functioning, ie. Did it indeed change the manner of student assessment?

(5) How do the teachers see their role and tasks in the operation of programme assemblies?

Our central hypothesis is that the reformed programmes did not produce the desired effect in these areas, since inadequate conditions prevented an increase in teacher autonomy; instead, the teaching profession was even more bureaucratised, thwarting the improvement of the conditions necessary for optimum student development.

\section{Method}

In our research we used secondary analysis of existing surveys, which allows researcher's access to data from large, national samples - data that would be difficult for a lone researcher to gather (Kiecolt \& Nathan, 1985). This analysis is not a specific regiment of analytic procedures or a statistical technique; it is the application of creative analytical techniques to data that have been amassed by others.

We will seek the arguments for our thesis in the evaluations conducted by the CPI between 2005 and 2012. This timeframe was chosen because with Slovenia's membership of the EU and the subsequent drawing of ESF funds, evaluation research on large samples and in multiple areas were made possible. But even before these evaluation reports were prepared and given to the expert public for critical review, the reform and introduction of all of the country's VET programmes was launched. The main reason for the simultaneous experimentation, evaluation and introduction of the curricular reform was financial: the funding for all activities was provided by the ESF, which operates in strictly defined timeframes within which successful spending is an important factor of success. For our analysis, we chose all those which, in our opinion, directly (Note 2) address the new or changed work tasks and teachers' responsibilities and the conditions for their implementation. We have systematically analysed evaluations made within the framework of the so-called Experimental Introduction and Monitoring of the Educational Programmes Mechatronics Technician and Design Technician (the experiment is conducted on eight schools). We disregarded evaluations made in a previous experiment (programme Car Mechanic) (Note 3) and paid special attention to differences caused by variations in sampling. Most evaluations involved broader representative samples (more programmes and schools than are actually included in the experiment), with reports always made separately for the experimental and total samples.

The following evaluations were included in our research:

\section{Curricular planning at the school level}

- The monitoring of the experimental introduction of educational programmes Mechatronics Technician and Design Technician. The research included the headmasters of all schools involved in the experiment $(n=7)$, all teachers teaching in the new and reformed programmes $(n=65)$, all students enrolled in these programmes $(\mathrm{n}=224)$ and 137 students' parents. (Klarič, 2008, 2009a)

- The monitoring of the concept of integrated key qualifications. The research was conducted on a representative sample of 305 teachers teaching in the programmes Vehicle Body Repairer, Car Mechatronic, Hairdresser, Cook, Industrial Mechanic, Carpenter, Mechatronics Technician and Design Technician. (Slivar, Milekšič, Cencen, Rau, \& Kovač, 2008) 


\section{Knowledge testing and assessment}

- The monitoring of the experimental introduction of educational programmes Mechatronics Technician and Design Technician. (Klarič, 2009a)

- The monitoring of student assessment. The research included 96 teachers teaching in the experimental programmes Mechatronics Technician and Design Technician. (Rutar-Ilc, Milekšič, Mažgon, Ribič, \& Klarič, 2008a)

- Evaluation of student assessment in reformed programmes. The evaluation included documents obtained from 5 schools. The following documents were analysed by learning units: teacher preparation, areas and criteria for assessment, minimum knowledge standards and student tests prepared by the teachers. (Rutar-Ilc \& Milekšič, 2008b)

\section{Teaching individualisation and differentiation}

- The second intermediate report on the monitoring of the experimental introduction of educational programmes Mechatronics Technician and Design Technician. The monitoring included 7 headmasters, 205 teachers, who are members of programme assemblies, and 286 students. (Klarič, 2009a; Ermenc, 2011)

- The monitoring of the individualisation and differentiation of the teaching process. The questionnaire was answered by 790 students enrolled in 22 vocational and professional schools, and 215 teachers. (Kalin, Valenčič, \& Vogrinc, 2008; Ermenc 2011)

\section{Personal study plans}

- The monitoring of the experimental introduction of educational programmes Mechatronics Technician and Design Technician. The research of the effects of personal study plans (PSP) on student education included 44 students in these programmes for whom PSP had been prepared, as well as 79 teachers and 8 consultants. (Klarič, 2009b)

- The monitoring of the implementation of personal study plans. The evaluation was conducted at 23 vocational and professional schools (out of 99 , which is over $23 \%$ of all vocational and professional schools). It involved 157 students for which PSP had been prepared, as well as 211 teachers and 25 consultants. (Slivar, Štirn-Janota, \& Vončina, 2009)

\section{Discussion}

\subsection{Evaluation of the Differentiation and Individualisation of the Teaching Process}

The evaluation of the differentiation and individualisation of the teaching process (Kalin et al., 2008; Klarič, 2009a) focused on the question of how much and how successfully the teachers practice internal differentiation and individualisation in their classes. Both internal differentiation and individualisation aim at providing better conditions for the optimum development of students and are among the basic principles of quality teaching and schooling. The evaluation recorded and compared the views of teachers and students.

What stands out is a huge discrepancy between the responses of teachers and students. From the teachers' responses, we could conclude that individualisation and internal differentiation were strengthened by the reform, while the data provided by students cast this into doubt. For example, over $70 \%$ of the teachers claimed that they sometimes or often prepare assignments at different difficulty levels for students with different abilities, while only $35 \%$ of the students confirmed that. Over $90 \%$ of the teachers claimed that they pay heed to the students' initiatives for teaching topics, while only $40 \%$ of the students confirmed that. Over $80 \%$ of the teachers and only $30 \%$ of the students claimed that the teachers often or always took the pre-existing knowledge of the students as the starting point. Over $95 \%$ of the teachers and $50 \%$ of the students reported that the teachers often or always strove to explain the topics in a manner that made them accessible to all students.

Such discrepancies are usually explained with the tendency of the respondents to provide the answers they consider desirable. To guess the desired answer, the teachers must have some information regarding what is desired, but need no detailed knowledge and understanding of the particular phenomenon. Of course, if the teachers merely provide the desired answers, we cannot directly conclude that they are inappropriately trained or underprepared, since we need data about their actual actions. Also, such discrepancies can be attributed to other factors-conceptual deficiencies of some of the new paradigmatic solutions, frequent changes of rules during the introduction of new programmes, organisational and financial restrictions, etc. However, the findings of the evaluation arouse suspicions that invite further investigation. 


\subsection{Evaluations of Curricular Planning at the School Level}

Further evidence that the problem of the discrepancy between the teachers' survey responses and their actions is at least partly due to inappropriate training comes from curricular planning at the school level. Several evaluations were made in this area, including evaluations of school curricula and the implementation of the concept of integrated key qualifications/competences (IKQ) in school curricula and pedagogical practice (Klarič, 2008, 2009a; Slivar et al., 2008).

The evaluations of school curricula showed (1) that only a small shift was made from content-based planning towards a greater balance between content-base and goal-based planning, which is a better basis for a comprehensive development of the students' vocational and professional competence; (2) that planning is fairly inflexible, which affects the individualisation of teaching; and (3) that vocational competences are strengthened by education which integrates general and vocational knowledge and on-the-job training, but such integration was fairly limited in the analysed curricula. This is not surprising, since such a radical change in the concept of planning requires great knowledge and thorough understanding. It is not a different working technique, but rather a change in the view of the purpose of knowledge and in the concept of vocational educatedness (further reading: Ermenc, 2006, 2007).

Although school curricula have largely not yet caught up with the changed epistemological basis of the national curricula, their preparation has introduced immense changes to the operation of schools. Teachers' teams spend a great deal of time and effort preparing the extensive and mandatory documentation. The work is done in teacher teams called programme assemblies (PA), usually led by teachers appointed by the headmaster. The leaders coordinate the work and function as a bridge between school leadership and the teaching staff (see Evaluation of PA performance).

The evaluations of the implementation of IKQ came to an important finding. The teachers' have a relatively poor knowledge of the concept of IKQ and individual IKQs. Nevertheless, they have no reservations assessing their qualities (attainability, usefulness, IKQ syllabus scope). The syllabi of the IKQs that the teachers do not know well and for whose implementation they feel less competent are assessed unfavourably, and those they know well and for which they feel more competent are assessed favourably.

\subsection{Evaluation of the Concept and Use of Personal Study Plans}

The personal study plan (PSP) was introduced in VET in 2005, but its function and structure changed in 2007. It was originally established as an instrument for students who required specific measures for their optimum development. It was to be based on the student's weak and strong points and prepared by an expert team, which should include the student him/herself. In 2007, two key changes were introduced. Firstly, the PSP became a mandatory, formalised instrument only for the students who failed to achieve the minimum standard of learning. Secondly, the PSP should be prepared by the teacher (or teachers) who determine that the student does not achieve the minimum standard of learning. The authors of the evaluation (Slivar et al., 2009; Klarič, 2009b) criticised such concept, saying that the new definition is too narrow since it excludes the students who achieve the minimum standards but have other specifics; it also excludes the highly gifted students. They also emphasised that PSP preparation is demanding expert work which must be done by a team consisting of various professionals. The evaluation shows that this change strengthened certain negative tendencies which had already been present in the PSP preparation process. The analysis of the surveys of teachers, consultants and students, as well as PSP case studies showed that (1) the teachers and consultants, in general, regard PSPs positively, while most students do not; (2) although the teachers and consultants, in general, regard PSPs positively, they have relatively low expectations regarding their positive effect on a student's success; the students also largely think that the PSP does not contribute to their success; and (3) the plans mainly contain only timelines for a student's tasks and lists of topics and learning forms, but they lack a thorough analysis of various failure factors, the student's weak and strong points and methods for supporting the student to overcome the weak points and strengthen the strong points. They lacked a strategy for strengthening the student's social network to assist $\mathrm{him} / \mathrm{her}$ in achieving these goals. We can only agree with the authors, who concluded that such formalisation of the procedures and narrowing of the PSP purpose strengthened the bureaucratic role of the teacher and the consultant. By doing this, they contribute neither to the optimum utility of the instrument nor to the optimum development of the students.

\subsection{Evaluation of Student Assessment}

The evaluation of the student assessment reform is particularly interesting for our purposes, since the authors (Rutar-Ilc \& Milekšič, 2008; Rutar-Ilc et al., 2008; Klarič, 2009a) compared the results of teacher and student surveys with the analysis of school documentation and examples of school tests. 
The authors evaluated the data from the standpoint of the criterion-based assessment-the paradigm which is the conceptual basis of the reform and is linked to the competence-based curricular design. In accordance with the concept, the state prescribed, as a mandatory part of the school curriculum, the preparation of the assessment plan (AP) and defined its key components. Its vital part is the definition of minimum standards of learning, since these are not defined in national syllabi. According to the logic of criterion-based assessment, the appropriate path from education aims to preparing tests is as follows: setting the targets, formulating standards of learning, preparing criteria and level descriptors for individual grades and, finally, preparing test questions and assignments.

The evaluation shows the following:

- Nearly $40 \%$ of the teachers consider the preparation of the AP as an imposition, though a majority at a general level recognise the benefits of the joint preparation for assessment in advance. The authors interpret this inconsistency as the teachers' resistance to an imposed change. Indeed, many teachers explicitly claimed that they understood the AP as a form of shifting the other institutions' responsibility onto them. Also, the analysis of materials and tests shows that whatever the institutions prepare to assist the teachers (syllabi, various manuals) is not used by the teachers. In particular, the teachers' lack of expertise to prepare proper standards of learning stands out.

- In the survey, the teachers claimed that they prepare tests with questions that required the application of knowledge. The analysis, however, showed that a huge majority of questions required only surface knowledge of the topics.

- The same discrepancy was seen in assessment criteria. The teachers reported that they prepared the criteria, but their analysis shows that the teachers did not know how to define the criteria in the manner required for criterion-based assessment (most understand them as percentages of correct answers).

- Finally, the authors observed that the goal standard criterion test path in most cases breaks down at the very beginning - at the standards. Although the teachers write them down faithfully (to avoid inspectors' sanctions), they are, in most cases, prepared so unprofessionally that they seem to serve no purpose. It is worth noting that the teachers in their answers admit that they, when preparing tests, usually rely on their own professional knowledge. This means that they do not utilise the knowledge they should have acquired during the preparations for the introduction of new programmes.

The evaluation confirms the thesis on the strengthened bureaucratisation of the teaching profession-a lot of work done for little effect. Since the teachers do not understand the new concepts and cannot apply them (what happened is an exceptionally large change, requiring a great deal of new knowledge and time to prepare the necessary documentation), their resistance is understandable. It would not be surprising if a new research showed that such work also causes considerable exhaustion.

\subsection{Evaluation of PA Performance}

VET reform is accompanied by a strong tendency to create more productive links between general and professional knowledge and to link theoretical and practical teaching. This ideal has been followed for several decades, but it has so far proven to be a hard nut to crack; the present reform characteristically attempts to use open curricula and more flexible financing to enable and encourage participation of the teaching staff, without whose expertise there can be no quality integration of knowledge and linking of theory and practice. This means that the engagement of the teaching staff became one of the key vehicles in attaining the goals of the reform.

As we have noted, the reform considerably strengthened the teachers' role as planners and evaluators; they became team workers. On one hand, this activates the school's internal developmental and creative potential, but on the other it requires a change to the teachers' pedagogical burden which prevents them from paying due attention to the new issues. The organisation of teams and the whole teaching process must become flexible enough to make their participation viable. Two practices have been introduced abroad: Spöttl, Prütz, and Grantz (2007) proposed the introduction of eight-hour teacher presence at the workplace and the assurance of appropriate conditions for individual and teamwork. The teacher's presence is required both for the organisation of teachers' meetings and for enabling more productive contacts among teachers and students.

The evaluation (Klarič et al., 2008; Klarič, 2009b) showed that the reformed programmes imposed additional tasks and responsibilities on the teachers. The results indicate that this causes a great deal of problems because of the inconsistencies between the traditional and new responsibilities. The corresponding legal documents, however, were not changed to address this new reality. It is therefore understandable that the greatest obstacle to teachers' participation is the lack of time and conditions for the meetings of teacher teams (it is interesting that, 
at a personal level, the teachers generally approve of this cooperation). The teachers, especially the PA leaders, are also displeased that the additional work is not rewarded. The PA has become a basic work unit within the VET; nevertheless, the role of the PA leaders is not legally defined, which causes problems at the level of work organisation and financing. The existing working conditions therefore affect the quality of the teachers' documents and their usefulness. Their preparation satisfies the legislator, but the teachers are even more removed from the students, not brought closer to them.

\section{Conclusions and Broader Significance of the Analysis}

The evidence supporting our thesis seems persuasive. However, we should not conclude that the strengthening of a teacher's autonomy as such is a mistake. The present concept of VET contains instruments which could contribute-and occasionally even now contribute-to a greater democratisation of in-school relations and to better conditions for optimum student development (open national curriculum, individual support for students, participation, etc.). But their positive potential is lost if the same instruments are abused for political and/or economic purposes, if the swiftness and content of the reform are dictated by the European (financial) policies and particularistic political interests, and/or if the school is reformed according to commercial laws (a "good" school should be capable of quick and flexible response to changed circumstances, cf. Laval, 2005). This article shows that the Slovenian educational system is already becoming burdened with paperwork, with little change for the better (cf. Fullan, 1991; Hargreaves, 2002; Ramberg, 2014). If the conditions do not change, we can expect even worse for the future-greater differences between schools and programmes in their quality and the quality of their students' achievements-which means an even greater loss of trust in vocational and professional education in general.

\section{References}

Bela knjiga o vzgoji in izobraževanju v republiki Sloveniji. (2011). [White Book on Education in the RS]. Ljubljana: Ministrstvo za šolstvo in šport.

Declaration of the European Ministers of Vocational Education and Training, and the European Commission, convened in Copenhagen on 29 and 30 November 2002, on enhanced European cooperation in vocational education and training "The Copenhagen Declaration". (2002). Retrieved from http://ec.europa.eu/education/policy/vocational-policy/doc/copenhagen-declaration_en.pdf

Ermenc, K. S. (2006). Racionalna evalvacija izvedbenih kurikulov in nacrtovanja projektnih dni v projektu 'Uvajanje in spremljanje novega izobraževalnega programa avtoserviser' in nekaj predlogov za izboljšavo [Rational Evaluation of School Curricula and Project Days Plan for the Project 'Introduction and Monitoring of the New Educational Programme Car Mechatronic' and a Few Suggestions for Improvement]. Ljubljana: National Institute for Vocational Education and Training.

Ermenc, K. S. (2007). Priprava izvedbenega kurikula: dva primera dobre prakse [Preparation of School Curriculum: Two Examples of Good Practice]. Ljubljana: National Institute for Vocational Education and Training.

Ermenc, K. S. (Ed.). (2012). Z evalvacijo do sprememb [With Evaluation to Changes]. Ljubljana: National Institute for Vocational Education and Training.

EURYDICE. (2008a). School Autonomy in Europe. Policies and Measures. Retrieved from http://eacea.ec.europa.eu/education/eurydice/documents/thematic_reports/090EN.pdf

EURYDICE. (2008b). Levels of Autonomy and Responsibilities of Teachers in Europe. Retrieved from http://eacea.ec.europa.eu/education/eurydice/documents/thematic_reports/094en.pdf

Fullan, M. (1991). The new meaning of educational change. London: Cassell.

Hargreaves, A. (2002). Sustainability of educational change: The role of social geographies. Journal of Educational Change, 3(3-4), 189-214. http://dx.doi.org/10.1023/A:1021218711015

Izhodišča za pripravo izobraževalnih programov nižjega in srednjega poklicnega izobraževanja ter programov srednjega strokovnega izobraževanja [Guidelines for the Preparation of Programmes for Lower and Middle Vocational Education and for Programmes of Technical Education]. (2001). Ljubljana: National Institute for Vocational Education and Training.

Kalin, J., Valenčič, Z. M., \& Vogrinc, J. (2008). Poročilo o spremljanju individualizacije in diferenciacije pedagoškega procesa [The report on the monitoring of the individualisation and differentiation of the teaching process]. Ljubljana: National Institute for Vocational Education and Training. Retrieved from http://www.cpi.si/razvojno-in-raziskovalno-delo/evalvacije-in-spremljanje/evalvacijska-porocila.aspx 
Kiecolt, K. J., \& Nathan, L. (1985). Secondary Analysis of Survey Data. Newbury Park: SAGE Publication. http://dx.doi.org/10.1023/A:1021218711015

Klarič, T. (Ed.). (2008). Prvo vmesno poročilo o spremljanju poskusnega uvajanja izobraževalnih programov Tehnik mehatronike in Tehnik oblikovanja [The first intermediate report on the monitoring of the experimental introduction of educational programmes Mechatronics Technician and Design Technician]. Ljubljana: National Institute for Vocational Education and Training. Retrieved from http://www.cpi.si/razvojno-in-raziskovalno-delo/evalvacije-in-spremljanje/evalvacijska-porocila.aspx

Klarič, T. (Ed.). (2009a). Drugo vmesno poročilo o spremljanju poskusnega uvajanja izobraževalnih programov Tehnik mehatronike in Tehnik oblikovanja [The second intermediate report on the monitoring of the experimental introduction of educational programmes Mechatronics Technician and Design Technician]. Ljubljana: National Institute for Vocational Education and Training. Retrieved from http://www.cpi.si/razvojno-in-raziskovalno-delo/evalvacije-in-spremljanje/evalvacijska-porocila.aspx

Klarič, T. (Ed.). (2009 b). Tretje vmesno poročilo o spremljanju poskusnega uvajanja izobraževalnih programov Tehnik mehatronike in Tehnik oblikovanja [The third intermediate report on the monitoring of the experimental introduction of educational programmes Mechatronics Technician and Design Technician]. Ljubljana: National Institute for Vocational Education and Training. Retrieved from http://www.cpi.si/razvojno-in-raziskovalno-delo/evalvacije-in-spremljanje/evalvacijska-porocila.aspx

Klarič, T., Ermenc, S. K., \& Vončina, V. (2008). Poročilo o delovanju programskih učiteljskih zborih v programih Tehnik mehatronike in Tehnik oblikovanja [The report on programme assemblies performance]. Ljubljana: National Institute for Vocational Education and Training. Retrieved from http://www.cpi.si/razvojno-in-raziskovalno-delo/evalvacije-in-spremljanje/evalvacijska-porocila.aspx

Koren, A. (2006). Avtonomija in decentralizacija v izobraževanju: študija vidljivosti v slovenskem šolskem sistemu [Autonomy and decentralisation in education: A study of visibility in the Slovenian school system]. Koper: Fakulteta za management; Ljubljana: Šola za ravnatelje.

Kovač, M. (Ed.). (2007). National Institute for Vocational Education and Training in Development of a Common European VET Area. Ljubljana: National Institute for Vocational Education and Training.

Kroflič, R. (1999). Avtonomija šole/vrtca in učitelja/vzgojitelja ali kako in kam bomo vozili v skladu z novo zakonodajo [School/kindergarten autonomy and teacher autonomy or how and where the new legislation will lead us]. Vzgoja in izobraževanje, 30 (pp. 7-9).

Laval, C. (2005). Šola ni podjetje: neoliberalni napad na javno šolstvo [School is not an enterprise: a neoliberal attack on public education]. Ljubljana: Krtina.

Lindblad, S., Lundahl, L., Lindgren, J., \& Zackari, G. (2002). Educating for the New Sweden? Scandinavian Journal of Educational Research, 46(3), 283-303. http://dx.doi.org/10.1080/0031383022000005689

Maastricht Communiqué on the Future Priorities of Enhanced European Cooperation in Vocational Education and Training (VET). (2004). Retrieved http://ec.europa.eu/education/policy/vocational-policy/doc/maastricht_en.pdf

Marentič, P. B., Kalin, J., Šteh, B., \& Valenčič, Z. M. (2005). Učitelj v prenovi-njihova strokovna avtonomija in odgovornost [Teachers in the reform-their professional autonomy and responsibility]. Ljubljana: Znanstveni inštitut Filozofske fakultete.

Medveš, Z. (2002). Ravnatelj in samoevalvacija [Headmaster and self-evaluation], Sodobna pedagogika, 53, pp. $28-46$.

Medveš, Z., \& Muršak, J. (Eds.). (1992). Sistemsko urejanje poklicnega izobraževanja: Zbornik [Systemic organisation of VET: Conference Book]. Ljubljana: Ministrstvo za šolstvo in šport.

Noordegraaf, M., \& De Wit, B. (2012). Responses to Managerialism: How Management Pressures Affect Managerial Relations and Loyalties in Education. Public Administration, 90(4), 957-973. http://dx.doi.org/10.1111/j.1467-9299.2012.02068.x

Peček, M. (1998). Avtonomnost učiteljev nekdaj in sedaj [Teacher autonomy in the past and present]. Ljubljana: Znanstveno in publicistično središče.

Pevec-Grm, S., \& Škapin, D. (Eds.). (2006). Kurikul na nacionalni in šolski ravni v poklicnem in strokovnem izobraževanju [Curriculum and the national and schools levels in VET]. Metodološki priročnik. Ljubljana: National Institute for Vocational Education and Training. 
Ramberg, R. M. (2014). What Makes Reform Work?-School-Based Conditions as Predictors of Teachers' Changing Practice after a National Curriculum Reform. International Education Studies, 7(6), 46-65. http://dx.doi.org/10.5539/ies.v7n6p46

Resman, M. (2002). Vzvodi šolskega razvoja [Levers of school development], Sodobna pedagogika, 53 (pp. 8-26).

Rutar-Ilc, Z., \& Milekšič, V. (2008). Evalvacija ocenjevanja v prenovljenih programih [Evaluation of student assessment in reformed programmes]. Ljubljana: National Institute for Vocational Education and Training. Retrieved from http://www.cpi.si/razvojno-in-raziskovalno-delo/evalvacije-in-spremljanje/evalvacijska-por ocila.aspx

Rutar-Ilc, Z., Milekšič, V., Mažgon, J., Ribič, S., \& Klarič, T. (2008). Spremljanje področja ocenjevanja [The monitoring of student assessment]. Ljubljana: National Institute for Vocational Education and Training. Retrieved from http://www.cpi.si/razvojno-in-raziskovalno-delo/evalvacije-in-spremljanje/evalvacijska-por ocila.aspx

Sahlberg, P. (2012). Rethinking Accountability in a Knowledge Society. Journal of Educational Change, 11, 45-61. http://dx.doi.org/10.1007/s10833-008-9098-2

Slivar, B., Milekšič, V., Cencen, Z., Rau, Z., \& Kovač, M. (2008). Spremljanje koncepta integriranih ključnih $k v a l i f i k a c i j$ [The monitoring of the concept of integrated key qualifications]. Ljubljana: National Institute for Vocational Education and Training. Retrieved from http://www.cpi.si/razvojno-in-raziskovalno-delo/evalvacije-in-spremljanje/evalvacijska-porocila.aspx

Slivar, B., Štirn-Janota, P., \& Vončina, V. (2009). Poročilo o spremljanju individualnega-osebnega načrta izobraževanja [The report on the monitoring of the implementation of personal study plans]. Ljubljana: National Institute for Vocational Education and Training. Retrieved from $\mathrm{http}$ ://www.cpi.si/razvojno-in-raziskovalno-delo/evalvacije-in-spremljanje/evalvacijska-porocila.aspx

Spöttl, G., Prütz, K., \& Grantz, T. (2007). Team Organisation at Vocational Technical Schools-A Key to Improve the Quality of Instruction. In QualiVET Project Group: Impuls. QualiVET Quality Development Framework (QDF). Leonardo da Vinci project (pp. 123-130).

Udosen, E. A. (2014). Learner Autonomy and Curriculum Delivery in Higher Education: The Case of University of Uyo, Nigeria. International Education Studies, 7(3) 40-50. http://dx.doi.org/10.5539/ies.v7n3p40

\section{Notes}

Note 1. This is in accordance with the Enlightenment view of the human being as an autonomous and rational creature which autonomy enables to make decisions in the laborious search for rational (competent) solutions to problems (Kroflič, 1999).

Note 2. For the purposes of this article we shall exclude those which provide indirect evidence; a comprehensive analysis of those remains a task for further research.

Note 3. These are less relevant for two reasons. Some problems they pointed out were solved or treated in greater detail in the second experiment.

\section{Copyrights}

Copyright for this article is retained by the author(s), with first publication rights granted to the journal.

This is an open-access article distributed under the terms and conditions of the Creative Commons Attribution license (http://creativecommons.org/licenses/by/3.0/). 